\title{
Political Economy in Security Studies After the Cold War
}

\author{
Jonathan Kirshner \\ Department of Government \\ Cornell University
}

CORNELL UNIVERSITY

PEACE STUDIES PROGRAM

OCCASIONAL PAPER \#20

CApril 1997 
C) 1997 Cornell University Peace Studies Program. All rights reserved.

ISSN 1075-4857

Political Economy in Security Studies After the Cold War

Jonathan Kirshner

The Peace Studies Program was established at Cornell in 1970 as an interdisciplinary program concerned with problems of peace and war, arms control and disarmament, and more generally, instances of collective violence. Its broad objectives are to support graduate and post-doctoral study, research, teaching and cross-campus interactions in these fields.

Copies of Occasional Papers may be ordered from:

Peace Studies Program

130 Uris Hall

Cornell University

Ithaca, NY 14853-7601 


\section{ACKNOWLEDGMENTS}

Earlier versions of this paper were presented at the University of California at Berkeley, as well as at Columbia, Cornell, Harvard, and Princeton Universities. Of the many who provided helpful comments and advice, I especially thank Rawi Abdelal, Peter Andreas, Tom Christensen, Mike Desch, Matt Evangelista, Aaron Friedberg, Peter Katzenstein, Beth Kier, Karl Mueller, Judith Reppy, Alan Rousso, and Barry Strauss. 


\section{TABLE OF CONTENTS}

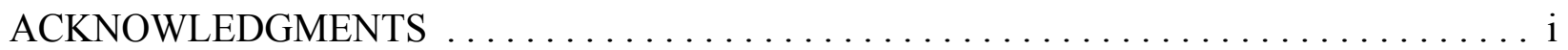

CLASSICAL ISSUES: THE UNDERLYING HARMONY $\ldots \ldots \ldots \ldots \ldots \ldots \ldots \ldots \ldots$

The Political Economy of Power $\ldots \ldots \ldots \ldots \ldots \ldots \ldots \ldots \ldots \ldots \ldots \ldots \ldots \ldots \ldots \ldots \ldots \ldots \ldots$

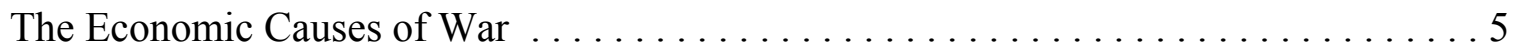

Strategy and the Budget Constraint $\ldots \ldots \ldots \ldots \ldots \ldots \ldots \ldots \ldots \ldots \ldots$

MODERN ISSUES: ACTION AND REACTION $\ldots \ldots \ldots \ldots \ldots \ldots \ldots \ldots \ldots \ldots \ldots$

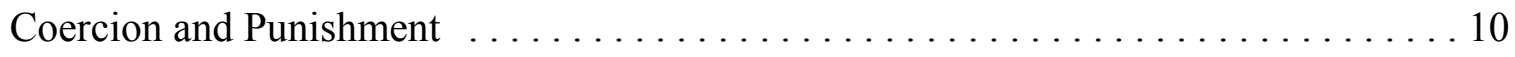

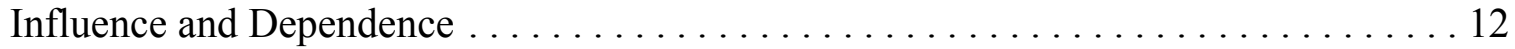

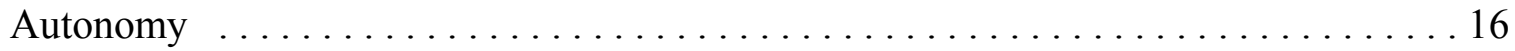

NEW CLASSICAL ISSUES: THE ECONOMIC SUSTAINABILITY OF SECURITY . . . . . 19

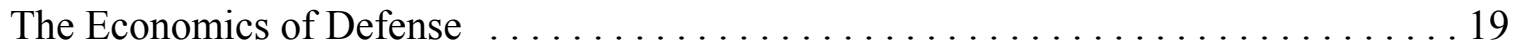

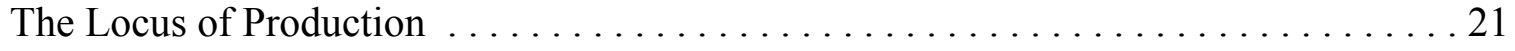

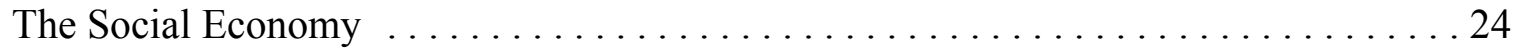

CONTEMPORARY INTERNATIONAL POLITICS $\ldots \ldots \ldots \ldots \ldots \ldots \ldots \ldots \ldots \ldots \ldots$ 


\section{POLITICAL ECONOMY IN SECURITY STUDIES AFTER THE COLD WAR}

In contemporary International Relations theory, there exists a sharp distinction between international political economy and security studies. This is largely a false distinction, however, a product of peculiar circumstances associated with the cold war, and one which is becoming increasingly anachronistic in the post-cold war era. In order to understand international relations in this era, a re-integration of the discipline is necessary.

During the cold war, there was a certain logic to the separation of political economy and security studies. The bipolar struggle dominated the security agenda. That conflict featured two states with little economic interaction - indeed, the Soviet Union did not even have a market economy. Thus, specialists in security affairs could comfortably marginalize economic relations, with some notable exceptions, such as the study of "economic containment." Similarly, the possibility of military conflicts among the advanced market economies seemed equally irrelevant in the context of the clearly drawn and stable battle lines of the cold war. Again, with specialized exceptions, such as burden sharing, ${ }^{2}$ students of political economy were able to minimize their concern for security. ${ }^{3}$

${ }^{1}$ See, for example, Gunnar Adler-Karlson, Western Economic Warfare 1947-67 (Stockholm: Almqvist \& Wiksell, 1968); Michael Mastanduno, Economic Containment: CoCom and the Politics of East-West Trade (Ithaca: Cornell University Press, 1992); Bruce W. Jentleson, Pipeline Politics: The Complex Political Economy of East-West Energy Trade (Ithaca: Cornell University Press, 1986).

${ }^{2}$ Mancur Olson and Richard Zeckhauser, "An Economic Theory of Alliances," Review of Economics and Statistics 48 (August 1966), pp. 266-79; Lincoln Gordon, "Economic Aspects of Coalition Diplomacy—The NATO Experience," International Organization 10:3 (August 1956), pp. 529-43. Recent reviews of these issues include John R. Oneal, "The Theory of Collective Action and Burden Sharing in NATO," International Organization 44:3 (Summer 1990), pp. 379-402; and John R. Oneal and Paul F. Diehl, "The Theory of Collective Action and NATO Defense Burdens: New Empirical Tests," Political Research Quarterly 47:2 (June 1994), pp. 373-96.

${ }^{3}$ According to Robert Keohane, "it is justifiable to focus principally on the political economy of the advanced industrialized countries without continually taking into account the politics of international security." After Hegemony: Cooperation and Discord in the World Political Economy (Princeton: Princeton University Press, 1984), p. 137. Security specialists have reached complementary conclusions, following Waltz's dictum that "Never in modern history have great powers been so sharply set off from lesser states and so little involved in each other's economic 
The cold war was also unique in that it featured actors - superpowers - who were much less sensitive to many of the issues that smaller but still great powers had to address throughout history, especially those associated with the political economy of national security. Superpowers, for example, did not face the budget constraints that states like Britain, France and Germany faced routinely and consequentially in the first half of this century. For most states, grand strategy involves making choices about interests in the context of scarcity. Similarly, due to their sheer size, dominance, and relatively small exposure to the international economy, the superpowers were less concerned about the consequences of economic interactions for preserving their autonomy, or calculating the distribution of relative gains, especially given the static alliance patterns of the era. ${ }^{4}$

Thus during the cold war, the nature of that conflict understandably but unnaturally bifurcated the discipline of IR into the distinct spheres of IPE and Security Studies. But these extraordinary and unprecedented circumstances are unlikely to be replicated in the foreseeable future. In order to understand contemporary international politics, IR theory needs to "return to normal." This paper is designed to explore the relationship between the two subfields, specifically with regard to how traditional security concerns are affected by issues normally associated with political economy. ${ }^{5}$ It reviews three sets of issues, tracing the evolution of these questions over time. First is a review of "classical" concerns, which also serves as a reminder of the essential integration of IR theory throughout history. This is followed by a consideration of modern issues, which arose as a consequence of the emergence of a truly international economy and were devel-

and social affairs." Theory of International Politics (New York: Random House, 1979), pp. 15152.

${ }^{4}$ Joanne Gowa, "Bipolarity, Multipolarity, and Free Trade," American Political Science Review, 83:4 (December 1989), pp. 1245-56.

${ }^{5}$ This is not intended to dismiss the importance of "new security issues," or the expanded role that political economy will likely play there. Rather, the focus of this paper on "traditional" security issues - defined here as war fighting capability, territorial integrity, and the projection of power and influence abroad-underscores the argument that political economy and security studies must be re-integrated, even if we were to retain the most narrow definition of security. On defining security, see Richard Ullman, "Redefining Security," International Security 8:1 (Summer 1983), pp. 129-53; also Barry Buzan, People, States and Fear: An Agenda for International Security Studies in the Post-Cold War Era, 2nd ed. (Boulder: Rienner, 1991). 
oped theoretically after the second world war. The third section focuses on new issues, which reflect the current manifestation of traditional concerns. A final section applies the conclusions of the theoretical parts of the paper to specific themes in the emerging international system.

\section{CLASSICAL ISSUES: THE UNDERLYING HARMONY}

Classical issues are those where the link between political economy and security studies is obvious and long recognized. They include the political economy of power, the economic causes of war, and the role of the national budget constraint on the construction and execution of grand strategy. In all three cases, it is impossible to conceptualize security without an explicit appeal to political economy. This synthesis has a two hundred year old tradition, traceable to the rise of liberal economic thinking and its influence on the perception of power.

\section{The Political Economy of Power}

As Viner has argued, while the mercantilists and the liberals may have disagreed on a number of issues, both schools of thought perceived an underlying long run harmony between the national pursuit of wealth and power. ${ }^{6}$ The liberal revolution in this regard was to change fundamentally the understanding of what wealth was. Traditional mercantilists stressed the accumulation of treasure - spending power that could buy weapons and support armies. Liberals argued that wealth was represented not by bullion but by productive capacity. On this point, the neo-mercantilist descendants of the discredited mercantilists embraced the liberals' logic. As Friedrich List argued, "The power of creating wealth is vastly more important than wealth itself." " Since that time, few have disputed that productive capacity is the base upon which military power rests. Paul Kennedy has argued, for example, that the course and outcome of the

\footnotetext{
${ }^{6}$ Jacob Viner, "Power vs. Plenty as Objectives of Statecraft in the Seventeenth and Eighteenth Centuries," World Politics 1:1 (October 1948), pp. 1-29.

${ }^{7}$ Friedrich List, The National System of Political Economy (Philadelphia: J.B. Lippincott \& Co., 1856), p. 208. Nor have liberals been blind to concerns for power. Adam Smith supported bounties for crucial defense industries - gunpowder and sail cloth — and supported the highly protectionist navigation acts in order to promote British shipbuilding. The Wealth of Nations (Chicago: University of Chicago Press, 1976 [1776]), volume I, pp. 484-85; volume II, p. 28. Representative of mercantilist thought is Thomas Mun, England's Treasure by Forraign Trade (New York: Macmillan, 1895 [1664]).
} 
First World War can be explained almost solely by evaluating the underlying economic capacity of the participants. ${ }^{8}$

Once productive capacity is recognized as the foundation of military power, a number of concerns are immediately brought to the fore. In order to fight wars, states may need to be concerned with their industrial capacity, steel production, access to energy (especially oil), technological capability, and other factors required to support a modern defense establishment. ${ }^{9}$ Access to finance has also been argued to be a crucial element of national security. ${ }^{10}$ Ultimately, with military power and influence deriving from economic power, economic stability and growth in general becomes a central national security concern. ${ }^{11}$ This is particularly true in the long runin the short run various decisions may be made for the sake of security which do not maximize wealth. But the underlying harmony is clear, and runs so deep that in practice it is difficult to disentangle the political and economic objectives of states in international relations. ${ }^{12}$

${ }^{8}$ Paul Kennedy, "The First World War and the International Power System," International Security 9:1 (1984), pp. 7-40. Clearly, for underlying economic power to affect the outcome of a specific war, the war must be of sufficient duration. This does not alter the basic point regarding the essential importance of productive capacity for national power.

${ }^{9}$ Klaus Knorr, The Power of Nations: The Political Economy of International Relations (New York: Basic Books, 1975); Hans Morgenthau, Politics Among Nations: The Struggle for Power and Peace (5th ed., rev.) (New York: Knopf, 1978), especially p. 126; Susan Strange, States and Markets (New York: Basil Blackwell, 1988); Kennedy, "First World War."

${ }^{10}$ Karen Rasler and William Thompson, "Global Wars, Public Debts, and the Long Cycle," World Politics 35:4 (July 1983), pp. 489-516; also Robert Gilpin, The Political Economy of International Relations (Princeton: Princeton University Press, 1987), especially pp. 328-36.

${ }^{11}$ On the importance of economic growth, see especially Robert Gilpin, War and Change in World Politics (Cambridge: Cambridge University Press, 1981); also Paul Kennedy, The Rise and Fall of British Naval Mastery (London: Ashfield Press, 1976).

${ }^{12}$ This is why Krasner argues it is difficult to separate realist from structural Marxist interpretations of foreign policy. Stephen Krasner, Defending the National Interest (Princeton: Princeton University Press, 1978), pp. 20-34. See also Viner, "Power versus Plenty," p. 10; Robert A. Pollard, Economic Security and the Origins of the Cold War, 1945-1950 (New York: Columbia University Press, 1985); Andrew J. Rotter, The Path to Vietnam: Origins of the American Commitment to Southeast Asia (Ithaca: Cornell University Press, 1987). 


\section{The Economic Causes of War}

Another subject obviously at the intersection of political economy and security studies, which can also trace its intellectual roots back well over one hundred years, is the economic causes of war. Manchester School economists in the nineteenth century, for example, saw a negative relationship between free trade and war. ${ }^{13}$ Others see conflict emerging from inter-state competition over access to markets and raw materials. ${ }^{14}$ More generally, Gilpin states that "in a world of scarcity the fundamental issue is the distribution of the available economic surplus," while Susan Strange sees the post-cold war era as one characterized by states "more directly engaged in the competition for shares of the world's wealth." 15

In practice, there are three principal ways in which economic forces act as a source of war: changes in relative economic growth, internal economic dislocation, and incompatible

${ }^{13}$ Representative of Manchester views is Richard Cobden, in a speech delivered in Manchester January 27, 1848, in his Speeches on Questions of Public Policy (New York: Klaus Reprint Co., 1970), pp. 233-41. Similar views were held by U.S. policy makers after the Second World War, who held that the closed international economy had contributed to the war. Highly critical of this argument are Edward H. Carr, The Twenty Years' Crisis, 1919-1939, 2nd ed. (New York: Harper, 1946), and Geoffrey Blainey, The Causes of War (New York: Free Press, 1973).

${ }^{14}$ Access to markets has been a staple of the radical literature, including V.I. Lenin, Imperialism: The Highest State of Capitalism (New York: International Publishers, 1985 [1917]); Thomas E. Weisskopf, "Capitalism, Socialism, and the Sources of Imperialism," in Testing Theories of Economic Imperialism, Steven J. Rosen and James R. Kurth, eds. (Lexington, MA: Lexington Books, 1974); and Gabriel Kolko, Confronting the Third World: United States Foreign Policy, 1945-1980 (New York: Pantheon Books, 1988). Economic roots conflict have been stressed by other writers, such as Lionel Robbins, The Economic Causes of War (London: Jonathan Cape, 1939); and Michael Howard, War In European History (Oxford: Oxford University Press, 1976). Securing energy supplies has been a particular focus of attention: see, for example, Charles Kupchan, The Persian Gulf and the West: The Dilemmas of Security (Boston: Allen \& Unwin, 1987); and David S. Painter, Oil and the American Century: The Political Economy of U.S. Foreign Oil Policy, 1941-1954 (Baltimore: Johns Hopkins University Press, 1986). On raw materials in general, see Ronnie D. Lipschutz, When Nations Clash: Raw Materials, Ideology, and Foreign Policy (Ballinger, 1989); and Raymond Vernon, Two Hungry Giants: The United States and Japan in the Quest for Oil and Ores (Cambridge: Harvard University Press, 1983).

${ }^{15}$ Gilpin, War and Change, p. 67; John Stopford and Susan Strange with John S. Henley, Rival States, Rival Firms: Competition for World Market Shares (Cambridge: Cambridge University Press, 1991), p. 204; see also pp. 209-11. 
national economic strategies. ${ }^{16}$ Changes in relative economic growth are argued to contribute to war by scholars who emphasize the importance of equilibrium between power and privilege in the international system. Under such conditions, states are satisfied with the status quo. ${ }^{17}$ According to this school of thought, because states tend to grow at differential rates, there is a natural impetus for the international system to drift away from equilibrium. Since power derives from underlying economic capacity, states that are growing faster perceive a divergence between their power and position in the international pecking order. Such states force a confrontation to revise the status quo, and this is often resolved by war. ${ }^{18}$

Internal economic dislocation can contribute to conflict for a number of reasons deriving primarily from the pressures that governments can find themselves under as a consequence of hard times. Such governments may resort to "military Keynesianism," that is, efforts at pump priming by expanded military spending. These measures can contribute to war by heightening the security dilemma, creating a militaristic mind-set, or by the purposeful extension of military Keynesian tactics. Hard times can also increase the perceived stakes in struggles for international economic opportunity. States may also engage in military adventures to divert attention away from failed domestic policies, or such dislocation may radicalize politics in general. The

\footnotetext{
${ }^{16}$ Wars can also be fought simply to reap the gains of conquest. See Peter Liberman, Does Conquest Pay? The Exploitation of Occupied Industrial Societies (Princeton: Princeton University Press, 1995). While the potential of such gains affects the cost-benefit calculus of going to war, it is only in a secondary sense that such incentives can be characterized an "economic force" that acts as "a source of war." Arguments regarding imperialism, market access and raw materials (see fn. 14) derive conflict and war from economic imperatives found within the expansionist state, and fall more obviously into the class of issues at interest here.

${ }^{17}$ Satisfied does not mean "happy," rather, simply that no state is willing to use force to change the status quo.

${ }^{18}$ Robert Gilpin, War and Change; George Liska, International Equilibrium: A Theoretical Essay on the Politics and Organization of Security (Cambridge: Harvard University Press, 1957); also his "Continuity and Change in International Systems," World Politics 16:1 (October 1963); A.F.K. Organski, World Politics (2nd ed.) (New York: Alfred A. Knopf, 1968), especially pp. 364-67; A.F.K. Organski and Jacek Kugler, The War Ledger (Chicago: University of Chicago Press, 1980); Charles F. Doran, "War and Power Dynamics: Economic Underpinnings," International Studies Quarterly, 27:4 (December 1983), pp. 419-40; and Paul M. Kennedy, The Rise of the Anglo-German Antagonism, 1860-1914 (London: Ashfield Press, 1980), especially pp. 291360 .
} 
interwar depression, for example, is often cited as contributing to the rise of Nazism in Germany and more broadly to the second world war. ${ }^{19}$

Conflicts can also be initiated or exacerbated by incompatible national strategies. Japan's inter-war grand strategy, for example, could not help but cause confrontation with the United States and Britain. Often such strategies unintentionally drive conflict as a consequence of the unintended effects of economic policies. Viner has argued, for example, that mercantilist strategies "served to poison international relations." Contrapositively, there is Kennedy's argument that one of the reasons why the British empire lasted so long was because its liberal international management ruffled few feathers. ${ }^{20}$ Additionally, economic strategies may not only be incompatible, they may backfire. French financial diplomacy in the inter-war period intended to influence German policy, for example, may instead have contributed to the deterioration of the situation. As Paul Einzig presciently argued in 1931, France's policy was short-sighted and invited self-defeating international financial chaos. He added "a collapse of the reichsmark is certain to bring about a complete political upheaval in Germany. It is highly probable that either the extreme nationalists or the communists will then acquire power. In either case, the French political influence over Germany would cease."21

\footnotetext{
${ }^{19}$ Norman Rich, Hitler's War Aims (New York: Norton, 1973), especially pp. 17-27; Arthur van Riel and Arthur Schram, "Weimar Economic Decline, Nazi Economic Recovery, and the Stabilization of Political Dictatorship," Journal of Economic History 53:1 (March 1993) pp. 71-105. On "hard times," Walter LaFeber, The New Empire: An Interpretation of American Expansion 1860-1898 (Ithaca: Cornell University Press, 1963). On domestic diversion, David Pion-Berlin, "The Fall of Military Rule in Argentina: 1976-1983," Journal of Interamerican Studies and World Affairs 27:2 (Summer 1985), pp. 55-76. See also Richard N. Rosecrance, Action and Reaction in World Politics: International Systems in Perspective (Boston: Little, Brown, 1963); and Jack Levy, "The Diversionary Theory of War: A Critique," in Handbook of War Studies, Manus Midlarsky, ed. (Boston: Unwin Hyman, 1989).

${ }^{20}$ Viner, "Power versus Plenty," p. 29; Michael A. Barnhart, Japan Prepares for Total War: The Search for Economic Security, 1919-1941 (Ithaca: Cornell University Press, 1987); Paul M. Kennedy, "Why did the British Empire Last So Long," in his Strategy and Diplomacy 18701945: Eight Studies (London: George Allen \& Unwin, 1983), pp. 197-218.

${ }^{21}$ Paul Einzig, Behind the Scenes of International Finance (London: Macmillan, 1932), p. 145.
} 


\section{Strategy and the Budget Constraint}

The incompatibility of national economic strategies calls attention to the issue of grand strategies in general. Avoiding unintended (and self-defeating) provocation is a necessary component of strategy, but it is not sufficient. Two central questions remain: how to form an optimal grand strategy, an exercise in setting priorities and reconciling ends and means; and what constraints are imposed on crisis and wartime operations by limited resources. These are issues at the heart of security studies - and they are also fundamentally questions of political economy. In fact it is notable that two concerns we have identified as central: economic growth and grand strategy, are the two principal questions on which the entire field of economics is based: (a) the causes of economic growth (the full title of Smith's book is An Inquiry Into the Nature and Causes of the Wealth of Nations), and (b) efficient allocation and distribution given scarcity (the essential microeconomic question).

To reiterate, the construction of grand strategy is a fundamentally economic question; further, a state's budget constraint defines the limits of its power. Understanding or failing to recognize these limits often makes the difference between successful and unsuccessful foreign policy. In the context of a crisis or war, retaining international solvency (particularly with regard to the balance of payments), mobilizing and extracting resources from society, and maintaining domestic economic stability are all crucial for success. These issues are ubiquitous and have been highly consequential. Financial problems plagued the Confederacy during the American Civil War, while during the Suez crisis, Britain was forced to renounce its operation in order to relieve pressure on the pound. Russia was unable to adequately harness its economy before and during the First World War. France was plagued by economic weakness during the Ruhr crisis and financial constraints contributed to British and French appeasement policies leading up to the second world war. ${ }^{22}$

\footnotetext{
22 Douglas B. Ball, Financial Failure and Confederate Defeat (Urbana: University of Illinois Press, 1991); Richard Bensel, Yankee Leviathan: The Origins of Central State Authority in America, 1859-1877 (Cambridge: Cambridge University Press, 1990); John Robert Ferris, Men, Money, and Diplomacy: The Evaluation of British Strategic Policy, 1919-1926 (Ithaca: Cornell University Press, 1989); Stephen A. Schuker, The End of French Predominance in Europe: The Financial Crisis of 1924 and the Adoption of the Dawes Plan (Chapel Hill: University of North Carolina Press, 1976); René Girault, "The Impact of the Economic Situation on the Foreign Policy of France, 1936-9," in The Fascist Challenge and the Policy of Appeasement, Wolfgang J.
} 
Clearly, there exists a rich tradition of integration between issues associated with political economy and security studies, which is essential to understanding state power as well as the causes and courses of conflict and war. ${ }^{23}$ The intellectual history of these issues can be traced to the 19th century and before, and the intimate association between the two was commonly assumed and understood prior to the cold war.

\section{MODERN ISSUES: ACTION AND REACTION}

Modern issues emerge from the consequences of linkages between political economy and security in the context of a well-developed international economy. The tugging and hauling of international economic influences - exposure to the international economy - and states' efforts to balance their desires for increased wealth and maximal security, create a distinct class of concerns for states. The increasing size of the international economy dating from the last quarter of the nineteenth century presented states with new sets of problems in the first half of the twentieth, and these concepts were developed theoretically in the second half of this century. The larger the state, however, the less intensely these issues are felt. As a result, they were least salient to the extraordinary superpowers, and not typically considered "high security issues" during the Cold War. With the end of the Cold War, the continuing expansion of the international economy, and the increasing number of states in the system, these issues will be of increasing consequence in the coming years. In this era, there will be more small states, and, more importantly, all states will be more like small states than they were in the past.

Mommsen and Lothar Kettenacker, eds. (London: George Allen \& Unwin, 1983); Robert Frankenstein, "The Decline of France and French Appeasement Policies," in Mommsen and Kettenaker; Diane B. Kunz, The Economic Diplomacy of the Suez Crisis (Chapel Hill: University of North Carolina Press, 1991); Peter Gatrell, Government, Industry, and Rearmament in Russia 1900-1914: The Last Argument of Tsarism (Cambridge: Cambridge University Press, 1994).

${ }^{23}$ It should be noted that this relationship runs both ways: war affects state power and capacity. On this question, see John Brewer, The Sinews of Power: War, Money, and the English State, 1688-1783 (New York, Alfred A. Knopf, 1989); Charles Tilly, Coercion, Capital, and European States, A.D. 990-1990 (Cambridge, MA: Blackwell, 1990); "War Making and State Making as Organized Crime," in Bringing the State Back In, Peter B. Evans, Dietrich Rueschemeyer and Theda Skocpol, eds. (Cambridge: Cambridge University Press, 1985); Michael C. Desch, "War and Strong States, Peace and Weak States?” International Organization 50:2 (Spring 1996), pp. 237-68. 


\section{Coercion and Punishment}

Efforts at economic coercion and punishment, or economic sanctions, have a bad reputation in the public perception and among scholars. Conventional wisdom holds that economic sanctions "don't work." This wisdom is flawed, however, and furthermore, economic diplomacy will play an increasingly large role in international relations. With the glue of the Soviet threat no longer in place, conflicts among the western allies will increase and be less constrained. These disputes will almost certainly be fought with economic as opposed to military techniques of statecraft. The collapse of communism has also increased the number of small, marketsensitive economies in the international system, which are particularly vulnerable to economic coercion. Additionally, several great powers, in particular the United States, Germany, and Japan, retain global interests but appear disinclined to use force to resolve most conflicts. For all these reasons students of security studies will need a greater understanding of economic statecraft.

Despite some notable advances in the past decade, particularly David Baldwin's Economic Statecraft, and also Hufbauer, Schott and Elliot's Economic Sanctions Reconsidered, our understanding of economic sanctions remains limited. ${ }^{24}$ The consensus regarding their limited utility has left them under-studied. But the belief that economic sanctions "don't work" is based on a number of errors, which are considered at length in Baldwin. In particular, (1) the failure to consider why economic sanctions were enacted; (2) the failure to compare costs; and (3) the failure to consider context, lead to analyses that understate the relative utility of sanctions.

\footnotetext{
${ }^{24}$ On sanctions, see David Baldwin, Economic Statecraft (Princeton: Princeton University Press, 1985); Gary Clyde Hufbauer, Jeffrey J. Schott, and Kimberly Ann Elliott, Economic Sanctions Reconsidered: Volume 1: History and Current Policy. Volume 2: Supplemental Case Histories, 2nd ed. (Washington, DC: Institute for International Economics, 1990); Klaus Knorr, Power of Nations; David Leyton-Brown, ed., The Utility of International Economic Sanctions (New York: St. Martin's Press, 1987); Robin Renwick, Economic Sanctions (Cambridge: Harvard Studies in International Affairs No. 45, 1981); Margaret P. Doxey, International Sanctions in Contemporary Perspective (New York: St. Martin's Press, 1987) and Economic Sanctions and International Enforcement, 2nd ed. (New York: Oxford University Press, 1980); M.S. Daoudi and M.S. Dajani, Economic Sanctions, Ideals and Experience (London: Routledge \& Kegan Paul, 1983); William H. Kaempfer and Anton D. Lowenberg, International Economic Sanctions: A Public Choice Perspective (Boulder: Westview Press, 1992).
} 
(1) Economic sanctions, designed to punish a state and change its behavior, are also enacted for additional reasons. One important one is signaling: sanctions can signal to friends and foes alike that you are opposed to an action and will take steps to counter it. It can provide moral support to opposition groups within the target, serve as a warning to others contemplating similar actions, and provide a boat-rocking function - warning that more extreme behavior may result in increasingly dramatic actions. ${ }^{25}$ So correctly assessing success or failure depends greatly on the entire range of outcomes the policy was designed to bring about.

(2) In arguing that economic sanctions "don't work," there is often an implicit comparison to other techniques of statecraft such as military force. But this comparison is almost always left undeveloped. Does military force "work"? This is an odd question, but a fundamental one. Clearly, force often fails. More importantly, success in statecraft is measured in political outcomes. As such, the costs— both political and economic — of a given technique of statecraft must be weighed against the political benefits of success. There may be many instances where military force would be unsuccessful and even more cases where the various costs of using force would be greater than the benefits of success. In those cases, force won't "work." Ultimately, it is unproductive to argue whether in the abstract, economic (or military statecraft) "doesn't work." Emphasis should be refocused to elucidate when different tactics will provide states with optimal policies, considering the various costs and benefits associated with different choices. No strategy can guarantee success: all one can hope to do is enact the "optimal" policy.

(3) Finally, it should be noted that it is impossible to evaluate the absolute power of a specific sanction (just as it is impossible to do so for a specific military action). Prospects for success depend on how much the adversary is willing to sacrifice, and this will be different from case to case, depending both on the value the target places on non-compliance and on the objective of the sanction. It is simply impossible to say whether a trade embargo that reduces GNP by $10 \%$ will "work" or not. Most likely, there will be cases when it will work and cases when it won't.

\footnotetext{
${ }^{25}$ On signaling and boat-rocking, see Thomas Schelling, The Strategy of Conflict (Cambridge: Harvard University Press, 1960), and Arms and Influence (New Haven: Yale University Press, 1966).
} 
Calling attention to these issues still leaves, and in fact increases, the need for additional research on economic sanctions. In particular two processes require further exploration: the relationship between the imposition of economic sanctions and the level of economic distress in the target, and the relationship between that domestic distress and policy change. These themes are derived from the folk wisdom regarding sanctions. When the sentiment is expressed that sanctions don't "work," this usually means one of two things: either the sanctions are unable to cause economic distress, or that distress is insufficient to change policy. Sanctions against Rhodesia, Nicaragua, and South Africa, for example were often said to have been unsuccessful because they were circumvented by networks of black markets, dummy corporations and other states' incentives to cheat. Sanctions against Panama, Iraq, and Serbia, on the other hand, have been able to cause great economic distress but that remarkable pressure did not translate into desired policy changes. ${ }^{26}$

\section{Influence and Dependence}

More subtle than coercion is the political economy of influence and dependence. Dependence results from asymmetries in economic relationships, and from the ways in which those asymmetries change states' preferences. Influence is the flip side of dependence: that which accrues to the dominant partner in an asymmetric relationship. The study of dependence goes back to Albert O. Hirschman's National Power and the Structure of Foreign Trade. ${ }^{27}$ Hirschman examined German interwar trading relations, demonstrating how Germany cultivated a series of asymmetric trading relationships with the small states of south-eastern Europe, as part

\footnotetext{
${ }^{26}$ I have argued elsewhere that a greater understanding of economic sanctions can be achieved with a "microfoundations" approach to economic sanctions, which disaggregates both the sanctions and targets. Only by better understanding the distinct attributes of specific tactics, and the diverse vulnerabilities of different domestic political structures, can sanctions be optimally employed. See Jonathan Kirshner, "The Microfoundations of Economic Sanctions" (unpublished paper, 1995). For an early example of this type of analysis, see Richard H. Ullman, "Human Rights and Economic Power: The United States versus Idi Amin," Foreign Affairs 56:3 (April 1978), p. 532. See also David Rowe, "Surviving Economic Coercion: Rhodesia's Responses to International Economic Sanctions," Ph.D. Dissertation, Duke University, Durham NC, 1993.

${ }^{27}$ Expanded edition, (Berkeley: University of California Press, 1980 [1945]).
} 
of its preWorld War II grand strategy. ${ }^{28}$ Small state participants in asymmetric economic relationships are much more sensitive to them than are their larger counterparts. Trade between Germany and Bulgaria, to take one example from Hirschman, could account for over half of Bulgaria's total trade while at the same time accounting for a trivial two or three percent of total German trade. Clearly, Bulgaria was more vulnerable to an interruption of trade than was Germany. This offered the latter considerable leverage over the former.

But dependence is not mainly about leverage, or coercion. It is distinct from coercion, and similar to what Nye has called "soft power." Instead of forcing others to do what you want them to do, soft power is about "getting others to want what you want." 29 Engaging in economic relations, especially those that involve discrimination - such as trade agreements or currency areas, alters the domestic political economy of each state. In asymmetric settings, this shift takes place almost entirely in the small state-its interests converge toward those of the dominant state. As an illustration, consider a small state reaching a free trade agreement with a large state. This causes convergence in three ways. First, the simple act of participation in the arrangement strengthens those who benefit from it relative to those who do not (by definition). This strength should translate into political power. ${ }^{30}$ Second, firms and sectors engage in patterns of activity based on economic incentives. This constellation of incentives is transformed when the state enacts the new trade agreement. Actors will respond to these incentives, and will form political coalitions to advance their interests. ${ }^{31}$ Decisions based on these new incentives give firms a stake in their nations' continued participation, and they will direct their political energies to that

${ }^{28}$ See also Allan G.B. Fisher, "The German Trade Drive in South-Eastern Europe," International Affairs 18:2 (March 1939), pp. 143-70.

${ }^{29}$ Joseph S. Nye Jr., Bound to Lead: The Changing Nature of American Power (New York: Basic Books, 1990), p. 188. Nye argues that "trends today are making . . . soft power resources more important." See also pp. 189-201.

${ }^{30}$ Gary S. Becker, "A Theory of Competition Among Pressure Groups for Political Influence," Quarterly Journal of Economics 98:3 (August 1983), pp. 373-400.

${ }^{31}$ Charles P. Kindleberger, "Group Behavior and International Trade" (1951), reprinted in Kindleberger, Economic Response: Comparative Studies in Trade, Finance, and Growth (Cambridge: Harvard University Press, 1986); Peter Gourevitch, Politics in Hard Times: Comparative Responses to International Economic Crises (Ithaca: Cornell University Press, 1986). 
end. As Hirschman noted, “. . . these regions or industries will exert a powerful influence in favor of a 'friendly' attitude towards the state to the imports of which they owe their interests." ${ }^{32}$ Third, the central government can find its own interests re-shaped, above and beyond the effects of domestic political pressures. ${ }^{33}$

It should be made clear that fostering dependence in order to enhance influence is undertaken by states using economic means to advance political goals. This is distinct from dependency, in which power is used to enforce economic extraction. Small states in dependent relationships such as those described above gain economically, both absolutely and relatively: indeed, this is the source of the influence. The United States bore significant costs and tolerated discrimination to promote its post-war trade and monetary regimes. Previously, Britain offered a number of incentives to solidify the sterling area, ${ }^{34}$ and this was true of the franc zone as well. One critic of the latter arrangement argued "from the economic point of view, it is hard to argue"

\footnotetext{
${ }^{32}$ Hirschman, National Power, p. 29. On sectors, see Kindleberger, “Group Behavior”; on coalitions, Gourevitch, Politics in Hard Times.

${ }^{33}$ This can result from concerns regarding the overall balance of trade, revenue from tariffs, or trade undertaken or controlled by the government. In general, governments themselves are more likely to be affected by monetary arrangements, such as participation in currency areas. Here, participation will affect the nature and capability of the government to provide monetary stability. Small states in monetary areas will also come to hold significant balances of the core currency, which creates an interest in the value and stability of that currency, as well as the general political fortunes of its issuer. See Jonathan Kirshner, Currency and Coercion: The Political Economy of International Monetary Power (Princeton: Princeton University Press, 1995), especially chapter 4 .

${ }^{34}$ Ian M. Drummond, The Floating Pound and the Sterling Area, 1931-1939 (Cambridge: Cambridge University Press, 1981), p. 254; Robert B. Stewart, "Instruments of British Policy in the Sterling Area," Political Science Quarterly 52:2 (June 1937), pp. 184-191; Philip W. Bell, The Sterling Area in the Postwar World: Internal Mechanism and Cohesion, 1946-1952 (Oxford: Clarendon Press, 1956), p. 18.
} 
that states were wrong in retaining membership. ${ }^{35}$ Even Germany's eastern European trading partners saw economic advantages from the deals they reached in the inter-war period. ${ }^{36}$

As with coercion, the mechanics of influence and dependence need to be more fully explored. This is particularly challenging because it is difficult to measure the "success" of these policies for large states. Unlike efforts at coercion, which aim to alter existing behavior, this form of statecraft, even when successful, works invisibly. Measuring altered preferences and their impact on policy decisions is problematic, especially given the challenge of establishing relevant counterfactuals. But powerful states have constantly attempted to use their economic resources to expand their influence. This has taken the form not only of efforts at trade and monetary arrangements, but also the manipulation of aid $^{37}$ and financial ${ }^{38}$ arrangements.

Such efforts are not always successful. Many states have been disappointed by the amount of influence they have been able to "purchase" for a given amount of aid. ${ }^{39}$ Manipu-

${ }^{35}$ Andrew M. Kamarck, The Economics of African Development (New York: Praeger, 1967), p. 225 (emphasis in original). See also Aguibou Y. Yansane, "Some Problems of Monetary Dependency in French-Speaking West African States," Journal of African Studies 5:4 (Winter 1978), pp. 444-70. International Monetary Fund (IMF), "The CFA Franc System," IMF Staff Papers, 10:3 (November 1963), pp. 357-60, 369, 376.

${ }^{36}$ Antonín Basch, The Danube Basin and the German Economic Sphere (New York: Columbia University Press, 1943), p. 178.

${ }^{37}$ David Baldwin, “The Power of Positive Sanctions,” World Politics 24:1 (October 1971), pp. 19-38; George Liska, The New Statecraft: Foreign Aid in American Foreign Policy (Chicago: University of Chicago Press, 1960); John D. Montgomery, Foreign Aid in International Politics (Englewood Cliffs, NJ: Prentice-Hall, 1967), and also his The Politics of Foreign Aid: American Experience in Southeast Asia (New York: Praeger, 1962); Jacob J. Kaplan, The Challenge of Foreign Aid: Policies, Problems, and Possibilities (New York: Praeger, 1967).

${ }^{38}$ Herbert Feis, Europe the World's Banker, 1870-1914: An Account of European Foreign Investment and the Connection of World Finance with Diplomacy Before the War (New Haven: Yale University Press, 1964 [1930]); Jacob Viner, "International Finance and Balance of Power Diplomacy, 1880-1914," Political and Social Science Quarterly 9:4 (March 1929), pp. 408-451; Feis, The Diplomacy of the Dollar: First Era, 1919-1932 (Hamden, CT: Archon Books, 1965 [1950]); Emile Moreau, The Golden Franc: Memoirs of a Governor of the Bank of France (Boulder: Westview Press, 1991), especially pp. 430-453.

${ }^{39}$ See Liska, New Statecraft; Desmond McNeill, The Contradictions of Foreign Aid (London: Croom Helm, 1981); Stephen M. Walt, The Origins of Alliances (Ithaca: Cornell University Press, 1987), especially p. 225. 
lating financial flows backfired both for Germany and France, in their efforts to influence Russia and Italy respectively, before World War I. But economic influence can be consequential. More importantly, states' interests evolve and are shaped by their economic relationships. This is of particular concern in periods of transition where interests are most contestable.

\section{Autonomy}

Influence and dependence refer to inter-state relations, including efforts by states to constrain the range of other states' behavior. For example, as recipients of aid or as members in preferential trading areas, states may refrain from engaging in certain behaviors that they expect would be incompatible with the preferences of their benefactors. This limits their options.

At the same time, there are more global international forces at work that challenge state power in a distinct way - they challenge the state's ability to function as an autonomous actor. Questions of autonomy differ from those of influence and dependence in that autonomy, as used here, refers to the power of the state vis-à-vis stateless forces: markets, firms, and individuals. These global market forces can limit and constrain policy, eroding overall national power.

There are a number of manifestations of increasing challenges to state autonomy: expanding international financial networks, enormous foreign exchange markets, increasingly complex international intra-firm trade, competition for foreign investment, and large migratory flows. These "market forces" present three problems for states: first, private actors may engage in patterns of activity that can diverge from the goals of government policy, creating domestic political barriers to some preferred policies. ${ }^{40}$ Second, and especially regarding issues of trade and foreign investment, there is the issue of control: whether the government will have the legal right or the practical capability to execute its chosen policies when dealing with transnational private actors. ${ }^{41}$ Included here are concerns for defense autonomy: the perceived need to have

\footnotetext{
${ }^{40}$ On these issues, see Benjamin J. Cohen, In Whose Interest? International Banking and American Foreign Policy (New Haven: Yale University Press, 1986), especially Part I.

${ }^{41}$ Raymond Vernon, Sovereignty at Bay: The Multinational Spread of U.S. Enterprises (New York: Basic Books, 1971); Edwin M. Graham and Paul R. Krugman Foreign Direct Investment in the United States, 3rd ed. (Washington, DC: Institute for International Economics, 1995); Peter Cowhey and Jonathan Aronson, "A New Trade Order," Foreign Affairs 72:1 (Supplement 1992-93), pp. 183-95; Ethan Kapstein, Governing the Global Economy: International Finance and the State (Cambridge: Harvard University Press, 1994).
} 
such control over industries crucial for national security. ${ }^{42}$ Third, particularly in the areas of finance, foreign exchange and foreign investment, there is the possibility that market reactions will undercut and even force a reversal of preferred policies. States need to be sensitive to the possibility that their policies may lead to capital flight, touch off speculation against their currencies, or discourage foreign investment.

It is this third set of issues which appear the most challenging to state autonomy in the contemporary international economy. Increased financial globalization has reduced macroeconomic policy autonomy, and this affects states' ability to increase defense spending, mobilize their military forces, or even engage in behavior that is perceived to risk war. ${ }^{43}$ Markets can be swift and decisive in imposing their discipline, as seen recently in Mexico. But limited macroeconomic policy autonomy is not restricted to small states, as seen most obviously in the well known French episode of the early 1980s. In that instance the socialist government of François Mitterrand was forced, after repeated inability to contain capital flight and following three deval-

${ }^{42}$ Aaron Friedberg, "The End of Autonomy: The United States After Five Decades," Christopher Mark Davis, "The Exceptional Soviet Case: Defense in an Autarkic System," Theodore Moran and David Mowrey, "Aerospace," and J. Nicholas Ziegler, "Semiconductors," all in Daedalus 120:4 (Fall 1991); Raymond Vernon, Deborah Spar, and Glenn Tobin, "Designing CoDevelopment: The Battle over the FSX Fighter," in their Iron Triangles and Revolving Doors: Cases in U.S. Foreign Economic Policymaking (New York: Praeger, 1991), pp. 55-80; Ethan Kapstein, "Losing Control: National Security and the Global Economy," The National Interest 18 (Winter 1989/90), pp. 85-90; Theodore H. Moran, "The Globalization of America's Defense Industries: Managing the Threat of Foreign Dependence," International Security 15:1 (Summer 1990), pp. 57-99. Michael Borrus and John Zysman, "Industrial Competitiveness and American National Security," in The Highest Stakes: The Economic Foundations of the Next Security System, Wayne Sandholtz, et al. (New York: Oxford University Press, 1992), pp. 7-52.

${ }^{43}$ These restraints are not obviously surmountable, as once unleashed, financial deregulation is difficult to contain. Eric Helleiner, States and the Reemergence of Global Finance: From Bretton Woods to the 1990s (Ithaca: Cornell University Press, 1994), especially pp. 12, 18, 152, 156, 196-98. See also J. Goodman and L. Pauly, "The Obsolescence of Capital Controls? Economic Management in an Age of Global Markets," World Politics 46:1 (October 1993), pp. 50-82; Andrew D. Cosh, Alan Hughes, and Ajit Singh, "Openness, Financial Innovation, Changing Patterns of Ownership, and the Structure of Financial Markets," in Financial Openness and National Autonomy: Opportunities and Constraints, Tariq Banuri and Juliet B. Schor, eds. (Oxford: Clarendon Press, 1992). For an argument that previous periods witnessed even greater financial integration, see Robert Zevin, "Are World Financial Markets More Open? If So, Why and With What Effects," in Banuri and Schor, Financial Openness. 
uations of the franc within eighteen months, to reverse course, abandon its expansionary macroeconomic policies, and introduce austerity measures that were more restrictive than those of its conservative predecessor. ${ }^{44}$ In this instance, France's national security was not at stake, nor were defense policies at the root of the crisis. But they easily could have been.

France's failure to respond to the German remilitarization of the Rhineland in 1936, for example, was influenced by a dramatic capital flight and speculation against the franc. The German action took place on Saturday March 7, and on the following Monday, selling pressure on the franc was sufficiently severe to bring about British intervention in the market. French hints that they might use force to remove the Germans were followed by a jump in the three month discount on the franc from eight to fourteen percent per annum. Shortly thereafter the French made it clear that they would not use force, and the pressure on the franc eased. ${ }^{45}$

State autonomy is increasingly challenged from many quarters, restricting policy options. In this issue area all states are becoming small states. While these forces can result in a number of different patterns of international relations, growing economic influences on security are inescapable. If states react to the expanding global market forces with a re-assertion of their autonomy, then the likely regionalization of the international economy will increase the significance of influence and dependence. ${ }^{46}$ If the market is left unchecked, then restrictions on policy

${ }^{44}$ Jeffrey Sachs and Charles Wyplosz, "The Economic Consequences of President Mitterrand," Economic Policy (April 1986), pp. 262-306; Michael Loriaux, France After Hegemony: International Change and Financial Reform (Ithaca: Cornell University Press, 1991); See also Paulette Kurzer, Business and Banking: Political Change and Economic Integration in Western Europe (Ithaca: Cornell University Press, 1993).

${ }^{45}$ Brendan Brown, The Flight of International Capital: A Contemporary History (London: Routledge, 1987), p. 71; see also Stephen Schuker, "France and the Remilitarization of the Rhineland, 1936," French Historical Studies 14:3 (Spring 1986), pp. 299-338; Frankenstein, "French Appeasement Policies," p. 237. Girault argues that "Appeasement, whether committed or temporizing, has its economic justification in the crying insufficiency of financial resources, caused essentially by the flight of capital" ("Foreign Policy of France," p. 223).

${ }^{46}$ Even if autonomy-seeking states move to re-establish control over market forces, regionalism or "minilateralism," not autarky, is the likely result. This is because security-conscious states must be sensitive to the importance of economic growth. Engaging the international economy provides expanded opportunities and greater prospects for growth. Thus such states face tradeoffs between complete autarky and unfettered internationalism in the pursuit of their multiple goals. Regionalism is the obvious compromise, combining relative autonomy with international 
autonomy will become more routine, consequential, and of necessity integrated into strategic planning.

\section{NEW CLASSICAL ISSUES: THE ECONOMIC SUSTAINABILITY OF SECURITY}

All states in coming years will find their security positions increasingly influenced by political economy. This will not be limited to the rise of modern issues - classical issues will also resurface in the post-cold war era, though in some cases, they will take distinct forms, and can be considered "new classical issues." New classical issues focus on the classical concern for economic growth as essential to power. In contemporary politics, this takes a number of forms which all focus around the issue of the economic sustainability of security. Ultimately, the Soviet Union fell not because of military weakness, but because of fundamental flaws in its political economy: its impressive military security system was not sustainable. Its defense burden became onerous, it fell further behind technologically, and was unable to produce economic growth. One sure lesson of the Cold War is that states cannot afford to ignore the importance of these factors.

\section{The Economics of Defense}

One way in which the issue of the economic sustainability of security surfaces is through the possibility that the myopic pursuit of military might erodes the economic base of the state. This became a popular item of concern during the Cold War. The Soviet Union was overwhelmed by its staggering defense burden, ${ }^{47}$ and there was concern that the U.S. military buildup might also undermine the U.S. economy. These concerns were popularized by Paul Kennedy in his book The Rise and Fall of the Great Powers, which held that such powers were histori-

economic opportunity. This result is predicted by scholars such as Gilpin, who states that "a mixed system of nationalism, regionalism, and sectoral protectionism is replacing the Bretton Woods system of multilateral liberalization." Because of these pressures, he concludes, "loose regional blocs are the likely result." Gilpin, Political Economy of International Relations, pp. 395 (first quote), 397 (second quote).

${ }^{47}$ See for example, Richard Cohen and Peter A. Wilson, Superpowers in Economic Decline: U.S. Strategy for the Transcentury Era (New York: Crane Russak, 1990), especially pp. 30-33. 
cally done in by military burdens bloated by strategic overextension. ${ }^{48}$ This argument had been stated theoretically by Gilpin, who argued that pressure for increased defense spending in mature hegemons was one factor that contributed to decreasing investment and thus slower economic growth. ${ }^{49}$ The high military burden of the United States, especially when compared to the spending of prosperous American allies such as Japan, was often cited as source of economic distress and poor economic performance. Posen and Van Evera Argued that "wasteful military spending is itself a national security threat, because it contributes to America's economic decline." ${ }^{50}$ Military spending is held to divert resources from the civilian sector, crowd out private investment, and pre-empt more productive forms of government spending. ${ }^{51}$

One comprehensive survey of the issue found that while it can provide a short term stimulus, in the long run military spending tends to have negative economic consequences. ${ }^{52}$ But this remains a hotly debated question, and the consequence of this conclusion, which is not universally accepted, is unclear. How much spending is "too much"? How detrimental is it? These questions are certainly raised by the U.S. case, where the dramatic increases in military spending

${ }^{48}$ Paul Kennedy, The Rise and Fall of the Great Powers: Economic Change and Military Conflict from 1500 to 2000 (New York: Random House, 1987); see also David P. Calleo, Beyond American Hegemony: The Future of the Western Alliance (New York: Basic Books, 1987); and E.A. Cohen, "When Policy Outstrips Power: American Strategy and Statecraft," The Public Interest 75 (1984).

${ }^{49}$ Gilpin, War and Change, p. 162. Gilpin argued that mature hegemonic states faced pressure to increase both defense spending and domestic consumption. Since gross national product can be divided into three shares - defense spending, consumption (private and public non-defense), and investment, if both defense and consumption are increased, investment must decrease as a share of GNP. Just as importantly, these pressures result in "an increasingly severe political conflict over the allocation of national income," that "transforms a relatively benign politics of growth into a more virulent politics of distribution" (pp. 166-7).

${ }^{50}$ Barry Posen and Stephen Van Evera, "Defense Policy and the Reagan Administration: Departure From Containment," International Security 8:1 (Summer 1983), p. 43.

${ }^{51}$ Robert W. DeGrasse Jr., Military Expansion, Economic Decline: The Impact of Military Spending on U.S. Economic Performance (New York: M.E. Sharpe, 1983). For similar (though less rigorous) arguments regarding the British experience, see Malcolm Chalmers, Paying For Defence: Military Spending and British Decline (London: Pluto Press, 1985).

${ }^{52}$ Steve Chan, "The Impact of Defense Spending on Economic Performance," Orbis (Summer 1985), p. 413. 
in the first half of the 1980s left a burden that was still lower as a percentage of gross national product than it had been in the 1950s and 60s. Further, the problems facing the U.S. economy were more likely the result of other factors, such as over-consumption, reflected in the fiscal and trade "twin deficits," which have macroeconomic consequences that dwarf those related to its defense spending. Finally, U.S. economic performance was superior to that of most of its allies in the 1980s. ${ }^{53}$ More generally, the exact trade-offs between defense spending and economic performance are hard to pin down. The effect of military spending, difficult to measure and compare across states, is also influenced by factors such as a state's level of development and its position in the business cycle. ${ }^{54}$

The relationship between defense spending and economic performance remains a com-

plex and contested issue. ${ }^{55}$ But the ultimate outcome of this debate does not change the fact that the provision of defense will affect the domestic economy, which in turn shapes the sustainability of state security, and that there remains a need for students of security to understand these relationships.

\section{The Locus of Production}

New classical issues emphasize the crucial role of economic growth in sustaining national security. Nowhere is this clearer than in the concern for the locus of production: what is

\footnotetext{
${ }^{53}$ Many of these criticisms were raised directly in response to Kennedy's book. Charles Kupchan, "Empire, Military Power, and Economic Decline," International Security 13:4 (Spring 1989), pp. 36-53; Aaron Friedberg, "The Political Economy of American Strategy," World Politics 41:3 (April 1989), pp. 381-406; W.W. Rostow, "Beware of Historians Bearing False Analogies,” Foreign Affairs 66:4 (Spring 1988), especially p. 866.

${ }^{54}$ Chan, "Impact of Defense Spending"; Miles Kahler, "External Ambition and Economic Performance," World Politics 40:4 (July 1988), pp. 419-51; J. Hollenhorst and G. Ault, "An Alternative Answer to: Who Pays for Defense," American Economic Review 65:3 (September 1971), especially p. 761; Kurt W. Rothschild, "Military Expenditure, Exports, and Growth," Kyklos 26 (1973), pp. 804-14; See also W. Robert J. Alexander, "The Impact of Defense Spending on Economic Growth," Defence Economics 2:1 (1990), pp. 39-55; Ming Wan, "A Century of Tradeoffs: Defense and Growth in the Japan and the United States," International Studies Quarterly 39:1 (March 1995), pp. 85-108.
}

${ }^{55}$ For a recent survey of this literature, see Steve Chan, "Grasping the Peace Dividend: Some Problems on the Conversion of Swords into Plowshares," Mershon International Studies Review 39:s1 (April 1995), pp. 53-95. 
produced where. This concerns the national interest because the composition of production can affect growth, because certain industries either have inherently superior growth trajectories, or they provide positive externalities to the greater economy.

The central question is whether government intervention is necessary to support such industries. This rests crucially on the concept of market failure: that the free market, left to its own devices, would produce sub-optimal economic outcomes. ${ }^{56}$ Market failures certainly exist, ${ }^{57}$ but it is necessary to identify them specifically in each case and explain how they can be eliminated by government intervention. For example, if industries offer high growth, why do private actors need any encouragement to invest in them? There are a number of possibilities: private actors may have shorter time horizons, greater risk aversion, or fewer resources than the government. Projects that do not offer returns for many years, or have a high probability of failure, or have great start-up costs may be underprovided by the private sector. In industries with economies of scale and other advantages to being the first producer, firms may be further inhibited from entry into otherwise promising ventures. This is complicated by "strategic" behavior-foreign governments (and firms themselves) engaging in measures designed to inhibit entry by others. Such action, it is often argued, can only be countered by competing government intervention. These arguments are not unique to the current era but they are increasingly salient in a world of activist governments and high technology industries. ${ }^{58}$

56 This need not be the justification for government intervention for other reasons, such as to preserve defense autonomy. In that case, economic growth is purposefully sacrificed to advance non-economic goals. Here, however, the concern is solely with long run economic growth, and thus intervention cannot be justified without the demonstration of market failure.

${ }^{57}$ See, for example George Akerlof, "The Market for 'Lemons'," Quarterly Journal of Economics 84:3 (August 1970), pp. 488-500. For a brief summary of the theory of market failure as it pertains to international trade, see Paul R. Krugman and Maurice Obstfeld, International Economics: Theory and Politics, 3rd ed. (New York: HarperCollins, 1994), pp. 232-6.

${ }^{58}$ Strategic behavior by both governments and firms is emphasized by Henri Hauser, Germany's Commercial Grip on the World: Her Business Methods Explained (London: Eveleigh Nash, 1917); "superiority antecedently enjoyed by nations" is stressed by Alexander Hamilton, "Report on the Subject of Manufactures," in Industrial and Commercial Correspondence of Alexander Hamilton, Arthur H. Cole, ed. (New York: A.M. Kelly, 1968 [1928]), pp. 247-77, p. 267; and Friedrich List, National System, p. 316. The "infant industry" argument is analyzed in W. Max Corden, Trade Policy and Economic Welfare (Oxford: Oxford University Press, 1974).

For the contemporary positions, see James A. Brander, "Rationales for Strategic Trade 
Some grounds for government intervention appear to be even more straightforward. There is a rich Pigovian tradition regarding externalities - those outputs from production not counted in firms' cost calculation. The existence of externalities means that there can be a divergence between private and societal levels of optimal production. This leads to an overproduction of negative externalities, such as pollution, or an underprovision of positive externalities, such as technologies with spin-off applications. As a result, the government should introduce taxes and subsidies to manipulate the production of externalities so that the private and societal optima are equated..$^{59}$

But even this minimal and compelling logic for intervention has been challenged. Coase has argued that size and scope for Pigovian taxes is much smaller than is usually acknowledged. And even this assumes that externalities can be identified and corrected. ${ }^{60}$ The problems mount even further in practice. Even if optimal policies could be calculated, would they be introduced? Critics suggest that "government failure" could lead to greater costs than market failure, and that industrial policies could lead to wasteful rent-seeking, crude protectionism, and invite foreign retaliation. ${ }^{61}$ Finally, there remains the danger that despite avoiding all of the pitfalls mentioned above, the government may still err. In the case of high-definition-television, for example, once

and Industrial Policy," in Strategic Trade Policy and the New International Economics, Paul R. Krugman, ed. (Cambridge: MIT Press, 1986); Gene M. Grossman, ed., Imperfect Competition and International Trade (Cambridge: MIT Press 1992); Laura D'Andrea Tyson, Who's Bashing Whom? Trade Conflict in High-Technology Industries (Washington, DC: Institute for International Economics, 1993); Richard J. Samuels: Rich Nation, Strong Army: National Security and the Technological Transformation of Japan (Ithaca: Cornell University Press, 1994).

${ }^{59}$ A.C. Pigou, Economics of Welfare (London: Macmillan \& Co., 1920), especially pp. 189-96.

${ }^{60}$ R. Coase, "The Problem of Social Cost," Journal of Law and Economics 3 (October 1960), pp. 1-44. On the difficulty of addressing externalities in practice, see Paul Krugman, "Introduction: New Thinking About Trade Policy," in Krugman, ed., Strategic Trade.

${ }^{61}$ Gene Grossman, "Strategic Export Promotion: A Critique," in Krugman, ed., Strategic Trade; Anne O. Krueger, "Free Trade is the Best Policy," in An American Trade Strategy: Options for the 1990s, Robert Z. Lawrence and Charles L. Schultze, eds. (Washington, DC: Brookings Institution, 1990). 
a rallying point for proponents of activism, U.S. producers currently have the advantage because subsidized European and Japanese competitors committed to the wrong technology. ${ }^{62}$

An additional danger regarding strategies designed to affect the locus of production is that they may oversell the importance of trade strategy's contribution to the national economy. ${ }^{63}$ Tyson herself notes that "misguided trade policies can be even worse than ineffective," and that “flawed domestic choices, not unfair foreign trading practices, are main cause of the nation's long-run economic slowdown." 64

\section{The Social Economy}

Whatever the merits of strategic trade and industrial policy, they do not appear to be of sufficiently great or unambiguous weight to place them within the first rank of new classical security concerns in the contemporary system. But they do call attention to the importance of the management of the domestic economy. While controversy persists regarding the locus of production, there is increasing consensus that government policies which "get the basics right" are an important element of economic growth. Instead of targeting sectors, such policies emphasize the economic foundations of society, such as education, infrastructure, incentives for savings and investment, and sound macroeconomic policies. ${ }^{65}$

${ }^{62}$ Steven Butler, “Japan's White Flag,” U.S. News and World Report 116:9 (March 7, 1994), p. 17; John Peterson, "Towards a Common European Industrial Policy? The Case of High Definition Television," Government and Competition 28:4 (Autumn 1993), pp. 496-511; Jeffrey Hart, "The Politics of HDTV in the United States," Policy Studies Journal 22:2 (Summer 1994), pp. 213-28. In yet another complication, it is not even clear that HDTV was a concern for "the locus of production," since in this case it is expected that due to its bulk and fragility, such units will be produced close to where they are consumed.

${ }^{63}$ For example, strategic trade policy is about the composition of trade, not the balance of trade. The source of trade deficits is to be found in macroeconomic relationships such as savings rates, and can only be corrected by policies which address those more fundamental questions rooted in the domestic economy.

${ }^{64}$ Tyson, Who's Bashing Whom? p. 2. These arguments are emphasized in C. Fred Bergsten and Marcus Noland, Reconcilable Differences? United States-Japan Economic Conflict (Washington, DC: Institute for International Economics, 1993).

${ }^{65}$ On new growth theory, see the various papers in "The Problem of Development," Journal of Political Economy 98:5/2 (1990); and "Symposium: New Growth Theory," The Journal of Eco- 
These concerns underscore a more fundamental issue for the sustainability of securitythe question of national vitality. Starting with "the basics" rooted in new growth theory, this also includes issues associated with the sociological foundation of long run economic growth. The incentive structure assures that actors will be encouraged to engage in activities that promote economic growth. Just as the absence of government intervention can lead to a divergence of private and social optima, excessive government regulation and taxation can have the same effect. Clear property rights and predictable legal structures also contribute to a convergence between private and social interests. ${ }^{66}$ At the same time, government intervention is crucial in a number of areas, particularly with regard to the provision of public goods, such as a sound infrastructure. Economic activity depends on efficient transportation networks, and this includes not only roads, bridges, rails, canals, and airports, but also the transmission of information. Further, these assets will not be fully utilized without sufficient investment in human capital, which is increasingly recognized as a fundamental source of economic growth. ${ }^{67}$

The economic sustainability of security is also sensitive to social cohesion. The erosion of national vitality, either from internal weakness or domestic conflict, affects not only future economic growth, but also the very ability of states to pursue grand strategies that may require short term sacrifices for long run benefits. In Gilpin's model of hegemonic decline, such factors as the corrupting influence of affluence and other social factors figure prominently. Many argue that British decline - especially the failure to adapt to the technologies of the second industrial revolution - was hastened by sociological factors including a sclerotic and stratified class struc-

nomic Perspectives 8:1 (Winter 1994). On "getting the basics right" in practice, Michael Porter, The Competitive Advantage of Nations (New York: Free Press, 1990); World Bank, The East Asian Miracle: Economic Growth and Public Policy (New York: Oxford University Press, 1993).

${ }^{66}$ Douglass C. North, Structure and Change in Economic History (New York: Norton, 1981).

67 "Human capital accumulation as the key source of growth and development is one of the major themes of the new economic development literature," Issac Ehrlich, "Development: Introduction," Journal of Political Economy 98:5/2 (October 1990), p. s7; see also Theodore W. Schultz, "Investment in Human Capital," American Economic Review 51:1 (March 1961), pp. 1-17. 
ture. ${ }^{68}$ Others, such as Olson, have emphasized the role of domestic distributional conflict in inhibiting economic growth — again, such conflict can also paralyze national strategy by reducing the central government's ability to mobilize domestic resources for foreign policy. ${ }^{69}$

One dimension of social cohesion is income distribution, which is an important new classical security issue that affects both current and future state power. With regard to current capabilities, sustained or increasing inequality may contribute to insurrection or rebellion (fundamentally reducing state power). ${ }^{70}$ But as emphasized above, even in the absence of these outcomes, increasing inequality and social conflict will restrict the state's capability to pursue optimal foreign policies due to the hyper-politicization of fiscal policy. Concerning future power, inequality may reduce economic growth. While it was traditionally assumed that a widening and narrowing of inequality was natural over the course of economic development, ${ }^{71}$ less attention was given to the role of distribution as an independent variable in explaining economic growth. While it is reasonable to assume that very high levels of equality would yield an incentive structure that could contribute to slower growth, high levels of inequality can also produce such

${ }^{68}$ Gilpin, War and Change, pp. 161-6; Correlli Barnett, The Collapse of British Power (Atlantic Highlands, NJ: Humanities Press International, 1986), especially pp. 95-97; and E.J. Hobsbawm, Industry and Empire: From 1750 to the Present Day (New York: Penguin, 1969), pp. 181-87, 192. Of course, other factors contributed to British decline, prominent among which was consequences of "going first," leaving competitors with the "advantages of backwardness." See Hobsbawm, pp. 187-91; W. Arthur Lewis, Growth and Fluctuations, 1870-1913 (London: George Allen \& Unwin, 1978), pp. 116-17.

${ }^{69}$ Mancur Olson, The Rise and Decline of Nations: Economic Growth, Stagflation, and Social Rigidities (New Haven, Yale University Press, 1982). On social conflict limiting government's ability to pursue national strategy, see, for example, Gatrell, Government, Industry and Rearmament in Russia.

${ }^{70}$ Albert Hirschman, "Changing Tolerance for Income Inequality in the Course of Economic Development," Quarterly Journal of Economics, 87:4 (November 1973), pp. 544-62. Mark Irving Lichbach, "An Evaluation of 'Does Economic Inequality Breed Conflict' Studies," World Politics 41:4 (July 1989), pp. 431-70; Edward Muller and Mitchell Seligson, "Inequality and Insurgency," American Political Science Review, 81:2 (June 1987), pp. 425-51.

${ }^{71}$ Simon Kuznets, "Economic Growth and Income Inequality," American Economic Review 45:1 (March 1955), pp. 1-28. 
dis-incentives. Recent research supports the view that economic growth is positively associated with relatively egalitarian distributions of income. ${ }^{72}$

In general, new classical issues serve as a reminder that security has both static and dynamic components. Static concerns, such as current force levels and postures are certainly important. But security is an inherently dynamic concept, and these dynamics rest on issues associated with political economy.

\section{CONTEMPORARY INTERNATIONAL POLITICS}

In the contemporary international system, all three sets of issues concerning political economy and national security will be of increasing importance. Modern issues will be routinely felt, as all states appear to be more and more like small states in their exposure to and size relative to the international economy. Concerns for coercion, influence, dependence, and autonomy will become routine, with the balance of these factors influenced by whether the international economy develops regionally or globally. The security implications of this evolution will be profound, but less dramatic than the challenges that will be raised by manifestations of classical and new classical issues in the short run. Three areas of the globe stand out as flash points in which political economy will shape the security structure and environment: China, Eastern Europe, and the United States.

China, with its dramatic economic growth and large absolute size, represents a classic example of the war-prone state according to equilibrium theories. Such theories hold that just as the external ambition of the United States, Germany, Japan, and the Soviet Union all increased commensurate with their economic expansion, as surely as day follows night China will be increasingly assertive in its quest for a place in the sun. Writing in 1988, Kahler argued that

\footnotetext{
${ }^{72}$ Torsten Persson and Guido Tabellini, "Is Inequality Harmful for Growth?" American Economic Review 84:3 (June 1994), pp. 600-18; Roberto Chang, "Income Inequality and Economic Growth: Evidence and Recent Theories," Federal Reserve Bank of Atlanta Economic Review 79:4 (July/August 1994), pp. 1-10; Dan Corry and Andrew Glyn, "The Macroeconomics of Equality, Stability, and Growth," in Paying for Inequality: The Economic Cost of Social Injustice, Andrew Glyn and David Miliband, eds. (London: Rivers Oram Press, 1994), pp. 205-16.
} 
international stability was likely to persist "until the elite of another ascendant power (China?) discovers the means to reinforce its military ambitions with economic success." $" 73$

This situation is exacerbated by the fact that the East Asian region is also populated by other states that are likely to have similar, if more modest expectations of playing a greater role on the world stage ${ }^{74}$ China, however, remains the central threat. The only factor mitigating this threat is the continuing decentralization and internationalization of the Chinese economy. Decentralization creates new centers of power within China that may inhibit adventurism, and internationalization, at least according to liberal theory, expands the possibility for bargaining and creates incentives to maintain peace. As a result, future Chinese behavior offers a test of competing theories of international relations. ${ }^{75}$

While China's growth is potentially destabilizing, the same is true of economic stagnation and decline in Eastern Europe and the Former Soviet Union. If China is analogous to Germany before the First World War, then this region resembles Germany after that conflict — where economic dislocation and despair contributed to the radicalization of politics and ultimately to war. Once again the peace - this time following the Cold War, has economic consequences. Keynes argued in 1919 that the post-war settlement "includes no provisions for the economic rehabilitation of Europe - nothing to make the defeated Central Empires into good neighbors, nothing to stabilize the new states of Europe, nothing to reclaim Russia."76 The same can be said for the "settlement" of the Cold War, which does not address the dramatic dislocative effects of the collapse of the Soviet empire. While there may be no obvious policy prescriptions, it should be noted that retaining economic stability in this region is a security concern, and

${ }^{73}$ Miles Kahler, “Ambition and Economic Performance,” p. 451.

${ }^{74}$ Denny Roy, "Hegemon on the Horizon? China’s Threat to East Asian Security," International Security 19:1 (1994), pp. 149-68; see also Aaron Friedberg, "Ripe for Rivalry: Prospects for Peace in a Multipolar Asia," International Security 18:3 (Winter 1993/4), pp. 5-33.

${ }^{75}$ A peaceful China is inconsistent with equilibrium theories such as those of Gilpin and Liska (see fn. 17). It is virtually inconsistent with realism, and would provide support for theories of interdependence. See Robert O. Keohane and Joseph S. Nye, Power and Interdependence: World Politics in Transition (Boston: Little Brown, 1977).

${ }^{76}$ John Maynard Keynes, The Economic Consequences of the Peace (New York: Penguin, 1988 [1919]), p. 226. 
further, that the pattern of economic arrangements which does emerge will have fundamental consequences for state power.

The United States faces a distinct challenge in the post-Cold War era. Triumphant in the Cold War and dominant militarily, the United States nonetheless faces grave threats with regard to the economic sustainability of its security. Victory has left the United States without a clear sense of purpose on the international scene, while at the same time, indicators suggest increasing social stresses. Median family income has exhibited no real net growth over the past twenty years, while income inequality has been increasing. Investment in future growth — especially in infrastructure and human capital— has not been sufficient. ${ }^{77}$ Such factors do not represent a present military challenge, but carry with them a steady erosion of U.S. power.

In fact, the single greatest security threat to the United States in the early post-Cold War era emanates from the internal atrophy of its national vitality. Social economic problems left unchecked will undermine economic growth and thus future power. They will also increase distributional conflict, making it extremely difficult for the government to mobilize the resources necessary to support far-sighted national goals. This represents a great danger for the international system as a whole, given the possibility that in the absence of a clear threat, these stresses in the U.S. economy will manifest themselves in increasing isolationism.

Regardless of the resolution of these three salient issues, it should be clear that in order to understand international relations in the post-Cold War era, it will be necessary to return to business-as-usual, in which the subfields of political economy and security studies are fully integrated.

\footnotetext{
${ }^{77}$ Lester Thurow, Head to Head: The Coming Economic Battle Among Japan, Europe, and America (New York: William Morrow, 1992). Stephan Klasen, "Growth and Well Being: Introducing Distribution-Weighted Growth Rates to Reevaluate U.S. Postwar Economic Performance," The Review of Income and Wealth 40:3 (September 1994), pp. 251-72; Martin Neil Baily, Gary Burtless, and Robert E. Litan, Growth With Equity: Economic Policymaking for the Next Century (Washington, DC: Brookings Institution, 1993).
} 